\title{
Importance of the Improvement in the Agricultural Technology of Sub-Saharan Africa on Local Economic Development and International Trade
}

\author{
Mihasina Harinaivo Andrianarimanana *(D) and Pu Yongjian
}

check for

updates

Citation: Andrianarimanana, M.H.; Yongjian, P. Importance of the Improvement in the Agricultural Technology of Sub-Saharan Africa on Local Economic Development and International Trade. Sustainability 2021, 13, 2555. https://doi.org/ $10.3390 /$ su13052555

Academic Editors: Philipp Aerni and Jungho Baek

Received: 14 January 2021

Accepted: 22 February 2021

Published: 26 February 2021

Publisher's Note: MDPI stays neutral with regard to jurisdictional claims in published maps and institutional affiliations.

Copyright: (c) 2021 by the authors. Licensee MDPI, Basel, Switzerland. This article is an open access article distributed under the terms and conditions of the Creative Commons Attribution (CC BY) license (https:// creativecommons.org/licenses/by/ $4.0 /)$.
School of Economics and Business Administration, Chongqing University, Chongqing 400044, China; puyjian@sina.com

* Correspondence: mihasina@cqu.edu.cn; Tel.: +86-130-4738-5428

\begin{abstract}
This study assesses the impacts of technological innovation in Sub-Saharan African agriculture on local and global economies. Using the Eaton-Kortum model, with $\theta=4.0875$, the results show that comparative advantage's positive impact on agricultural trade more than offsets the negative impacts of geography barriers. Sub-Saharan Africa is among the least competitive region with respect to agriculture production. This is due to its low value of the technology parameter, about 0.16 compared to the North American's one (93.23). We found that increasing the technology of a country in Sub-Saharan Africa would increase world trade volume within the range of 0.02 to $0.19 \%$. It would increase the local agricultural monthly wage and the welfare of farmers in the Sub-Saharan African region. Therefore, to improve technology in the Sub-Saharan African region, policymakers need to attract foreign direct investment by making incentives and increasing labor skills. This study adds to the literature by determining the contribution of the agricultural sector in Sub-Saharan Africa in global economic development through international trade. It also informs policies on the reduction of poverty and food insecurity around the world in order to achieve some of the Sustainable Development Goals.
\end{abstract}

Keywords: agriculture; competitiveness; Eaton-Kortum model; international trade; Sub-Saharan Africa; sustainable development goal; technology

\section{Introduction}

According to mercantilism, international trade is a way for a country to acquire wealth by maintaining a trade surplus, which means a higher export value than import value [1]. Since the sixteenth century when the mercantilism theory first emerged, debates among economists and policymakers have persisted regarding the role of international trade in promoting economic development [2].

With four out of five people below the international poverty line living in rural areas, poverty reduction efforts need to primarily focus on increasing agricultural productivity, especially in Sub-Saharan Africa and in South Asia. Those two regions comprise $20 \%$ and $35 \%$ of the world's rural population, respectively [3]. In general, countries from these two regions suffer from low production and inefficient use of technology in the agricultural sector [4-6]. Consequently, to meet the first objective of the Sustainable Development Goals (SDG), least developed countries (LDCs) need to increase their productivity to alleviate poverty. Higher agricultural productivity will in turn increase the global food supply to address the second SDG objective of achieving food security [7].

Sub-Saharan Africa is host to $13 \%$ of the global population [8]. The agricultural sector in the region has a high potential [9], but is still underperforming due to lack of technology [10]. The region also accounts for $50 \%$ of uncultivated world land [11]. Hence, technological innovation and investments are required to improve agricultural productivity in Sub-Saharan Africa [12]. Moreover, with the SDG, the world is now facing the challenge 
of eradicating hunger and poverty. Therefore, improvements in the agricultural sector in Sub-Saharan Africa are precariously needed [13].

Adam Smith, in 1776 [14], introduced the first-ever concept of international trade: the theory of absolute advantage. Since then, a wide range of literature and research on the raison d'être of the international trade has been published, going from the concept of comparative advantage introduced by David Ricardo (1817) [15], the revealed comparative advantage developed by Balassa (1965) [16], the approach of Krugman (1979) [17] using economies of scale and market extension, to the log-supermodularity measure of Costinot (2009) [18]. The concept of comparative advantage introduced by Ricardo is the most famous and widely used trade theory [15]. Ricardo proposed that countries should specialize in the sector in which they have a comparative advantage and should export the products from this sector [19-21]. Over time, researchers extended the original model with a factor endowments approach [22-24], a continuum of goods implementation [25,26], and a probabilistic approach with many countries and goods [27]. Empirically, most research focus on the manufacturing sector at the country and firm-level [18,25,27-32].However, to date, there has only been a few studies on the agricultural sector, especially in Sub-Saharan Africa [33-35].

This study assessed the potential impact of improving technology in agriculture in Sub-Saharan Africa in order to achieve the second SDG by 2030. We used the Ricardian model developed by Eaton and Kortum, henceforth EK, to capture the impact of comparative advantage on agricultural trade. We used the results from the EK model to determine the competitiveness of Sub-Saharan Africa in agriculture. Next, the study investigated whether competitiveness in Sub-Saharan Africa mostly stemmed from labor productivity versus wage and other inputs such as fertilizer. Finally, we ran a counterfactual analysis to assess the effects of technological improvement in agriculture on global and regional economies. This study used labor productivity, as measured by output per worker, instead of yield to proxy for the technology of each country. By using labor productivity, agricultural performance is less correlated to the land variable [35] and more related to labor performance and labor characteristics.

The paper is divided into 5 sections: Section 1 introduces the work, Section 2 describes the materials and methods used, Section 3 reports the results, Section 4 discusses the findings, and Section 5 concludes.

\section{Materials and Methods}

\subsection{Study Area}

Sub-Saharan Africa includes 46 countries geographically located to the south of the Sahara Desert. Due to data availability, we used 11 individuals Sub-Saharan Africa countries in our sample: Burundi, Cameroon, Cote d'Ivoire, Ethiopia, Ghana, Guinea, Kenya, Madagascar, Malawi, Niger, and South Africa. The majority of the Sub-Saharan African population (70\%) live in rural areas and depend on agriculture. Between 2000 and 2020, Sub-Saharan Africa's agricultural sector used $40 \%$ of world land area, enrolled 50 to $60 \%$ of the region's employment, and generated 15 to $20 \%$ of the region's GDP [3]. Furthermore, agriculture is one of the sectors with a positive balance of trade for the region [36].

To estimate the EK model, we used data from several countries. Ideally, we should have used all countries of the world, but due to lack of data, we were unable to do so. Thus, we applied Costinot and Donaldson's principle in 2012 [33] and selected countries with high agricultural production. We took all the countries for which the data required for the model computation was available, which are (1) wages, (2) product prices, (3) production value, and (4) trade volume. As a result, 66 individual countries were selected and used. Data for selected countries were gathered from FAOSTAT [37], a database widely used in agricultural studies and literature [6,33-35,37]. 


\subsection{The Eaton-Kortum Model}

This study used a multi-country model based on technology differences, developed by EK. The model used labor as the only factor of production and drew the productivity under a probabilistic law à la Fréchet distribution given by Equation (1)

$$
F_{i}(z)=e^{-T_{i}} z^{-\theta}
$$

Subject to $T_{i}>0 ; \theta>1$, where $z$ is the productivity, $T_{i}$ is the absolute advantage across the continuum of goods specific to country $i$, and $\theta$, captures the relative efficiencies across goods. The force of comparative advantage weakens with higher $\theta$ denoting less variability within the distribution.

The parameter $\theta$ was estimated using Equation (2)

$$
\frac{\frac{X_{\mathrm{ni}}}{X_{\mathrm{n}}}}{\frac{X_{i i}}{X_{i}}}=\left(\frac{\mathrm{p}_{\mathrm{i}} \mathrm{d}_{\mathrm{ni}}}{\mathrm{p}_{\mathrm{n}}}\right)^{-\theta}
$$

where $X_{n i}$ is the share of agricultural goods that country i buys from country $n, X_{n}$ is the total expenditure of country $n$ in agricultural products, and $p_{i}$ and $p_{n}$ represent the average agricultural price of the importers (country i) and the exporters (country n), respectively. As it is proposed in the EK paper and adopting the methods used by Reimer and $\mathrm{Li}$, we capture prices using producers' average price [27,35]. The variable $\mathrm{d}_{\mathrm{ni}}$ is the distance markup following Samuelson's iceberg transportation assumption $\left(\mathrm{d}_{\mathrm{ii}}=1\right.$ and the triangular inequality).

We used two different methods to obtain an estimation for $\theta$ : First, the method of moments estimator, and second the two-stage least square estimation (2SLS). Referring to the findings from previous literature and the characteristic of Equation $(1)(\theta>1)$, we suggested that the value of $\theta$ related to agriculture should be between $(1,8.28)$ [27]. A value of $\theta$ that laid outside this interval means that the agricultural products are homogenous, which is unrealistic. The method of moments is often used in the literature of international trade $[28,29]$, and allows to overcome the heteroskedasticity problem. It consists of taking the mean of the left-hand-side variable over the mean of the right-hand-side variable of equation (2) [27]. We will discuss the 2SLS after the presentation of the technology parameters estimation.

Technology parameters $\left(T_{i}\right)$ in (1), represents the ability of the labor in each country to use their input to produce agricultural goods efficiently, obtained using Equation (3),

$$
\mathrm{T}_{\mathrm{i}}=\left(e^{S_{i}} w_{i}^{\theta}\right)^{\beta}
$$

where $w_{i}$ is the minimum wage, and $S_{i}$ is the competitiveness estimated using Equation (4). Because agriculture is a low-income sector activity in Sub-Saharan Africa $[5,6,18]$, we used the minimum wage instead of the average wage to compute the model.

$$
\ln \frac{X_{n i}^{\prime}}{X_{n n}^{\prime}}=-\theta \operatorname{lnd}_{n i}+S_{i}-S_{n}
$$

with

$$
\ln X_{n i}^{\prime}=\ln X_{n i}-[(1-\beta) / \beta] \ln \left(X_{i} / X_{i i}\right)
$$

where $S_{n}$ is the destination effects and $\beta$ is the agricultural labor constant share. The variable $\mathrm{d}_{\mathrm{ni}}$ was decomposed as follow: interval of physical distance, sharing a border, sharing the same language, regional trade agreement, destination effects, and error term. To deal with zeros value of the left-hand-side of Equation (4), we used the Poisson pseudo maximum likelihood (PPML) estimation. Instead of using a logarithmic transformation, PPML allows the dependent variable to take its level value [38]. 
The 2SLS consists of estimating $\theta$ with Equation (4) but we used Equation (5) to express the right-hand-side of Equation (4) and take the observed physical distance and the exporter and importer fixed effect as instrumental variable.

$$
D_{n i}=\frac{\max _{j}\left\{\ln p_{n}(j)-\ln p_{i}(j)\right\}}{\sum_{j=1}^{j}\left[\ln p_{n}(j)-\ln p_{i}(j)\right] / J}
$$

In Equation (5), we used the second largest value of the distribution, denoted $\max 2_{j}$, instead of the maximum in order to address possible measurement errors in the prices of goods.

Finally, to identify the source of agricultural competitiveness we used Equation (6), derived from Equation (3)

$$
S_{i}=\sum_{j=1}^{3} \beta_{F} \ln \left(\text { Fertilizer use }_{i}\right)+\beta_{L} \ln \left(\text { Labor Productivity }_{i}\right)+\beta_{E} \ln \left(\text { Export }_{i}\right)+\beta_{\text {wln }}\left(\text { Wage }_{i}\right)
$$

where $j$ is nutrient nitrogen, nutrient phosphate, and nutrient potash use, representing the intensity of fertilizer input use per hectare for each country. Fertilizer use and labor productivity capture the technology parameters, and exportation value is useful in the sense that competitiveness relies on it.

\subsection{Counterfactual Analysis}

This analysis was used to assess the effects of increasing agricultural technology in Sub-Saharan Africa on the local, regional, and global economies. For that, we simulated a higher value of the technology parameters in Equation (1) to analyze impacts on welfare, wage, labor, and global trade volume.

In this sub-section, we followed three steps. First, we solved the equilibrium of the model using labor market clearing conditions as in the original EK model [27]. The equilibrium was set using the parameters of the model $\left(T_{i}\right.$ and $\left.\theta\right)$ as well as the wage, distance, and labor variables. We considered two main characteristics of the factor of production. We used both mobile labor (agricultural labor can switch to another sector) and immobile labor (agricultural labor is not able to move to another sector). We chose to use both mobile and immobile labor to highlight the difference in the impacts of technological improvement according to country labor characteristics. From computing the equilibrium, we obtained a baseline value corresponding to welfare, wage, price, and global agricultural trade volume. Second, as the equilibrium condition is expressed with $T_{i}$, we simulated the impact of a technological innovation by increasing $\mathrm{T}_{\mathrm{i}}$ (from Equation (3)) within the assumption that the distance variable remains the same. Finally, with the simulated $T_{i}$, we recomputed the equilibrium to get a new simulated value for welfare, wage, price, and global agricultural trade volume. The difference between the baseline value and the new simulated value represents the effect of the technological improvement. Here, welfare is set using GDP per capita and is explained by the wage and price of agricultural goods.

\subsection{Statistical Analysis}

The difference between the value of the competitiveness, the technology parameters, and the wage of each sub-region was assessed with a statistical analysis using the software SPSS statistics version 20 (IBM corporation). First, we determined the distribution of the data using the Kolmogorov-Smirnov test. Second, if the data had a normal distribution, we ran a $t$-test, and if not, we used a Mann-Whitney test for two groups and the KruskalWallis test for $\mathrm{k}$ groups. We used a confidence level of $95 \%$. To identify the source of competitiveness for the sub -regions, we used Equation (3) and Equation (6). Since competitiveness depends on technology and wage, we sought to explain competitiveness using these two variables. We also test the possible effect of labor productivity and wage productivity on competitiveness. For that, we regrouped sub -regions into two groups 
according to their competitiveness. Using values of the parameter technology and wage, we ran the appropriate test as outlined above.

\section{Results}

\subsection{Data Description}

For this study, $25 \%$ of the dependent variable had zero values. Developed countries (USA, Japan, and France), emerging countries (Brazil and China), developing Asian countries (Thailand and India), and African countries (Madagascar, Burundi, Cote d'Ivoire, Egypt, and Algeria) have 5\%, 10\%, 20\%, and $40 \%$ of data that were zeroes, respectively. Through our data screening, we found that developed countries have a higher trade volume than African countries. In this instance, the U.S. is the largest importer and exporter with 13,000 and 14,000 million USD/year, respectively. While Burundi is the smallest exporter with only 4 million USD/year traded. We also found that Sub-Saharan Africa has a low average wage. Burundi is the country with the lowest monthly wage (4.2 USD/month), whereas the monthly wage in Germany is the highest (2800 USD/month). Generally, African countries have a low capital devoted to agricultural research and development $(R \& D)$, the lowest agricultural productivity, and the lowest education attainment compared to other countries.

\subsection{Estimation of Parameter $\theta$}

From the method of moments estimation, we found $\theta=4.0875$. Table 1 summarizes the results of the estimation of parameter $\theta$ using 2SLS.

Table 1. Two stage least square estimation of $\theta$.

\begin{tabular}{ccccccc}
\hline & Wald chi2(1) $=\mathbf{4 0 . 9 7}$ & \multicolumn{3}{c}{ Instrumented $\mathbf{D}_{\text {ni }}$} \\
\hline & \multicolumn{2}{c}{ Prob $>$ chi2 $\mathbf{~} \mathbf{0 . 0 0}$} & \multicolumn{3}{c}{ Instruments Distance, Fixed Effect } \\
\hline $\mathrm{Y}$ & Coef. & Std. Err. & $\mathrm{z}$ & $\mathrm{P}>|\mathrm{z}|$ & $95 \%$ Conf. Interval \\
\hline $\mathrm{D}_{\mathrm{ni}}$ & -0.52 & 0.08 & -6.40 & 0.00 & -0.68 & -0.36 \\
$\theta$ & -7.17 & 0.13 & -52.30 & 0.00 & -7.44 & -6.90 \\
\hline
\end{tabular}

Table 1 shows a value of $\theta=7.17$, with significant impact on the dependent variable. We also found that $\theta$ has a larger effect than $D_{\text {ni }}$ on explaining the trade share. Taking into account the confidence interval of $\theta$ in Table 1 of $(6.90 ; 7.44)$, both values of $\theta$ fall between $(1,8.28)$ which implies higher heterogeneity of agricultural products compared to manufacturing ones. In absolute terms, comparative advantage has a larger impact on trade than the resistance imposed by geographic barriers $d_{n i}$.

\subsection{Agricultural Competitiveness}

\subsubsection{Competitiveness Estimation}

Table 2 reports the coefficient values of the competitiveness variables $S_{i}$ from the PPML estimation. A positive coefficient of competitiveness indicates that the country is more competitive than the average competitiveness of the sample $(\bar{S}=0)$. Twelve out of fifteen countries in Africa and nine out of sixteen countries in Asia is not competitive (with a negative coefficient). For the European continent twelve out of twenty-one countries are competitive. Finally, the United States, Canada, as well as Latin American countries (except Bolivia) have a positive coefficient of competitiveness. Within Sub-Saharan Africa, least to most competitive countries are Ethiopia, Madagascar, Ghana, Malawi, Niger, Kenya, Burundi, Cameroon, South Africa, Guinea, and Cote d'Ivoire. With the three-last countries with a positive coefficient. Cote d'Ivoire and South Africa had the highest GDP of Sub Saharan Africa sample, 11 billion and 121 billion USD, respectively. Guinea's $p$-value $(>0.05)$ suggest that for this country competitiveness does not explained its trade flow. 
Table 2. Estimates of the competitiveness variables $S_{i}$ from the Poisson pseudo maximum likelihood (PPML).

\begin{tabular}{cccccc}
\hline Country & Coef. $^{1}$ & Country & Coef. ${ }^{1}$ & Country & Coef. ${ }^{\text {1 }}$ \\
\hline Hong Kong & $-5.11(0.00)$ & Serbia & $-1.57(0.00)$ & Australia & $2.01(0.00)$ \\
Iran & $-0.38(0.22)$ & Spain & $2.11(0.00)$ & New Zealand & $0.77(0.00)$ \\
Israel & $-1.19(0.00)$ & Sweden & $-0.22(0.69)$ & Bangladesh & $-2.77(0.00)$ \\
Japan & $-0.48(0.47)$ & Turkey & $0.72(0.01)$ & India & $1.48(0.00)$ \\
Korea & $-1.70(0.00)$ & Ukraine & $0.65(0.00)$ & Nepal & $-0.83(0.03)$ \\
Russia & $-0.11(0.80)$ & UK & $0.89(0.01)$ & Cambodia & $0.78(0.00)$ \\
China & $2.54(0.00)$ & Argentina & $2.74(0.00)$ & Indonesia & $0.44(0.002)$ \\
Armenia & $-0.99(0.00)$ & Bolivia & $-0.74(0.02)$ & Malaysia & $0.60(0.018)$ \\
Austria & $-0.98(0.00)$ & Brazil & $2.42(0.00)$ & Philippines & $-1.37(0.00)$ \\
Belgium & $0.75(0.00)$ & Chile & $0.54(0.02)$ & Saudi Arabia & $0.21(0.47)$ \\
Bulgaria & $-1.27(0.00)$ & Colombia & $0.51(0.17)$ & Thailand & $1.96(0.00)$ \\
Denmark & $0.55(0.05)$ & Costa Rica & $0.14(0.68)$ & Burundi & $-0.57(0.00)$ \\
Finland & $-1.91(0.00)$ & Ecuador & $0.19(0.53)$ & Cameroon & $-0.53(0.05)$ \\
France & $1.99(0.00)$ & Mexico & $0.03(0.94)$ & Côte d'Ivoire & $0.87(0.00)$ \\
Germany & $1.12(0.00)$ & Peru & $0.17(0.40)$ & Ethiopia & $-2.78(0.00)$ \\
Greece & $0.07(0.77)$ & Venezuela & $1.36(0.00)$ & Ghana & $-1.65(0.00)$ \\
Hungary & $0.11(0.67)$ & Algeria & $-3.31(0.00)$ & Guinea & $0.49(0.50)$ \\
Ireland & $-0.36(0.22)$ & Egypt & $-0.63(0.03)$ & Kenya & $-0.59(0.05)$ \\
Italy & $0.79(0.00)$ & Morocco & $-0.91(0.00)$ & Madagascar & $-2.33(0.00)$ \\
Netherland & $1.00(0.00)$ & Tunisia & $-0.97(0.00)$ & Malawi & $-1.13(0.00)$ \\
Portugal & $-0.09(0.86)$ & Canada & $1.73(0.00)$ & Niger & $-0.75(0.03)$ \\
Romania & $-1.10(0.00)$ & USA & $3.42(0.00)$ & South Africa & $0.42(0.06)$ \\
\hline 1 p-values are reported in parentheses. & & & &
\end{tabular}

Figure 1 presents the average competitiveness of each sub-region. Sub-Saharan Africa, North Africa, South Asia, and Asia's average competitiveness is lower than the sample average $(\approx 0)$. Values of the regional competitiveness are $-0.78,-1.46,-0.71$, and -1.49 , respectively. However, North America, Europe, Central Asia, Latin America, Oceania, and Southeast Asia have higher competitiveness in the agricultural sector $(2.57,0.10,2.54,0.74$, 1.40 , and 0.44 , respectively).

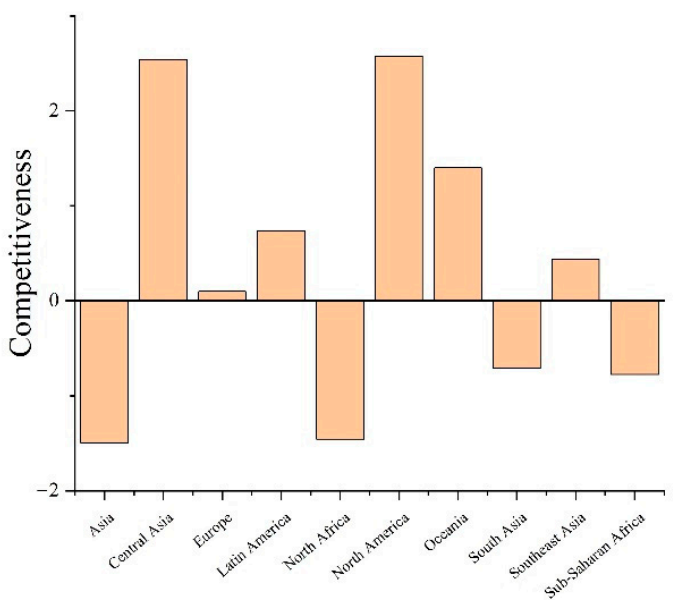

Figure 1. World competitiveness in the agricultural sector.

Table 3 reports the results of the t-test $(\alpha=0.05)$ run on the coefficient of $S_{i}$. We divided the sample into two groups, the first group aggregated the sub-regions with low competitiveness (negative coefficients $\mathrm{S}_{\mathrm{i}}$ ), and the second group combined the sub-regions with high competitiveness (positive coefficients $S_{i}$ ). The difference between the mean of the two groups is significantly different from 0 with a $p$-value lower than 0.0001 . 
Table 3. T-test on the sub-region with negative coefficient and positive coefficient.

\begin{tabular}{cc}
\hline Difference & -2.33. \\
$\mathrm{t}($ Observed value) & -9.69 \\
$|\mathrm{t}|$ (Critical value) & 1.99 \\
$p$-value (Two-tailed) & $<0.0001$ \\
Alpha & 0.05 \\
\hline
\end{tabular}

\subsubsection{Technology, Wage, and Labor Productivity}

We used $\theta=4.0875$ for our estimation because $\theta=7.17$ could mislead our conclusion because the value is near the upper bound of our interval and $\theta=4.0875$ are very similar to the literature findings. Table 4 exhibits the average technology parameters for each sub -region. The value of the technology parameters for Sub-Saharan Africa and South Asia are the lowest out of all regions, 0.16 and 0.09 , respectively. North America, especially the U.S, is the most productive with a value of the technology parameter equal to 132.84 . We can observe the high gap between this extremum value. Within the Sub-Saharan Africa sample, South Africa, and Cote d'Ivoire have the highest values for technology parameters, 0.62 and 0.43, respectively. Recalling the results from Section 3.3.1. South Africa and Cote d'Ivoire have the highest competitiveness coefficients and Ethiopia has the lowest. The Kruskal Poisson pseudo maximum likelihood Wallis test $(\alpha=0.05)$, using values of the parameter $\mathrm{T}_{\mathrm{i}}$ on the sub-regions shows a significant result $(p$-value $=0.0001)$. The differences between some of the medians are statistically significant. It indicated that technology differences are statistically different and possibly explain the source of competitiveness for some sub -region.

Table 4. Other variables presentation.

\begin{tabular}{cccc}
\hline Sub-Region & Technology $\left(\mathbf{T}_{\mathbf{i}}\right)^{\mathbf{1}}$ & Labor Productivity $^{\mathbf{2}}$ & Minimum Wage $^{\mathbf{3}}$ \\
\hline North America & 93.23 & 97.37 & 833.72 \\
Europe & 65.30 & 34.70 & 957.07 \\
Oceania & 48.73 & 50.51 & 723.82 \\
Asia & 10.57 & 37.93 & 411.67 \\
Southeast Asia & 5.21 & 5.27 & 181.73 \\
Latin America & 2.45 & 27.51 & 131.44 \\
Central Asia & 0.91 & 0.99 & 52.55 \\
North Africa & 0.39 & 3.51 & 68.13 \\
Sub-Saharan Africa & 0.16 & 1.37 & 31.91 \\
South Asia & 0.09 & 0.34 & 21.93 \\
\hline
\end{tabular}

${ }^{1}$ Result from Equation (3); ${ }^{2}$ Thousand USD/Labor; ${ }^{3}$ USD/month/Labor.

Sub-Saharan Africa and South Asian sub-regions have the lowest monthly minimum wages (31.91 and 21.93 USD/month, respectively), while the European sub -region has the highest monthly minimum wage (957.07 USD/month) (Table 4). The difference between the monthly minimum wage of each sub-region was significant according to the results from the Kruskal-Wallis test ( $p$-value $=0.0011$ ).

In terms of labor productivity, the Kruskal-Wallis test $(\alpha=0.05)$ returns a significant result, suggesting a high gap among countries. Overall, North America, Oceania, Europe, Latin America, and Asia have a higher labor productivity than Central Asia, South Asia, and Africa. Again, South Africa and Cote d'Ivoire have the highest labor productivity of 8.28 and 1.18 thousand USD/labor/year respectively, and Ethiopia the lowest, generating 0.15 thousand USD/labor/year.

\subsubsection{Source of Competitiveness for Each Sub -Region}

As mentioned in Section 2.4., we performed the upper-tailed Mann-Whitney test $(\alpha=0.05$, using the same groups in Section 3.2. to identify the source of each entity's 
competitiveness. We found that the difference in technology between the two groups was significant $(p$-value $\leq 0.0001)$.

Table 5 reports the results from the regression run on Equation (6), and shows that variation in competitiveness is explained by the variation in the independent variable by $42 \%$. Labor productivity has a positive and significant impact on competitiveness. If we increase labor productivity by one percent, we expect competitiveness to increase by 0.0029 units. Unsurprisingly, export has a positive and significant impact on competitiveness. However, the use of nutrient nitrogen negatively and significantly affects competitiveness, one percent increase in nitrogen use decreases competitiveness by 0.0041 unit. The use of other inputs has a positive impact on competitiveness, but the coefficient is not significant. It is worth noting that the sign of the coefficient of the covariates wage return the expected sign as in Equation (3). However, this negative impact has not a significant effect on the competitiveness. These results suggest that low competitiveness of Sub-Saharan Africa is explained by the technology parameters, the labor productivity, and by inadequate use of fertilizer.

Table 5. Source of competitiveness.

\begin{tabular}{ccccccc}
\hline \multicolumn{2}{c}{ Prob $>\mathbf{F}=\mathbf{0 . 0 0}$} & \multicolumn{5}{c}{ R-Squared $\mathbf{0 . 4 2}$} \\
\hline Si & Coef. & Std. Err & $\mathbf{t}$ & $\mathbf{P}>|\mathbf{t}|$ & \multicolumn{2}{c}{ Conf. Int. } \\
\hline Lab. Prod. & 0.29 & 0.13 & 2.26 & 0.03 & 0.03 & 0.56 \\
$\quad$ Wage & -0.41 & 0.34 & -1.20 & 0.23 & -1.09 & 0.27 \\
Fert. use 1 & -0.44 & 0.20 & -2.16 & 0.03 & -0.85 & -0.03 \\
Fert. use & 0.19 & 0.24 & 0.83 & 0.41 & -0.28 & 0.66 \\
$\quad 12$ & & & & & & \\
Fert. use & 0.17 & 0.16 & 1.07 & 0.29 & -0.15 & 0.50 \\
$\quad 13$ & 0.58 & 0.11 & 5.21 & 0.00 & 0.36 & 0.81 \\
Export ${ }^{1}$ & -9.27 & 2.07 & -4.46 & 0.00 & -13.42 & -5.11 \\
$\quad$ cons & -9.27 &
\end{tabular}

${ }^{1}$ Excluding the export variable from the regression returns a positive and significant effect of the labor productivity variable on competitiveness with $p$-value equal 0.008 and R-squared 0.15 .

\subsection{Counterfactual Analysis}

This section discusses the results from the simulation outlined in Section 2.3.. Technology improvement in Sub-Saharan Africa is subject to many challenges [39,40]. Instead of increasing our technology parameters by $100 \%$, to avoid overestimation, we choose to increase it by $25 \%$. We present the simulation results for the Sub-Saharan Africa countries with the highest and lowest impacts on international trade volume (Burundi and Ethiopia, respectively) in this section. Table 6 shows value in percentage change of the variable welfare $\left(\mathrm{W}_{\mathrm{i}}\right)$, the agricultural price, the agricultural labor, and the share of agricultural expenditure from the baseline value to the counterfactual value.

Technology improvement has a positive impact on local markets in Sub-Saharan Africa. The increase of $25 \%$ of the technology parameters in Sub-Saharan Africa country induces an increase of agricultural wage in the local economy and a decrease of price in the foreign market. According to Table 6, if we increase the technology parameters in Burundi or in Ethiopia, wage increases by $8 \%$ in both countries in case of immobile labor. When we allowed labor to move across sector, technology improvement attracts labor into the agricultural sector of the local economy (around 20\%). The percentage change in wage and labor are almost the same for every Sub-Saharan Africa country with a variation of $+/-1$. 
Table 6. Burundi and Ethiopia simulation results.

\begin{tabular}{|c|c|c|c|c|c|c|c|c|c|}
\hline & \multirow{2}{*}{ Country } & \multicolumn{4}{|c|}{ Mobile Labor ${ }^{3}$} & \multicolumn{4}{|c|}{ Immobile Labor ${ }^{3}$} \\
\hline & & $\mathrm{Wi}^{1}$ & Price & Labor & $\alpha^{2}$ & $\mathbf{W i}^{1}$ & Price & Wage & $\alpha^{2}$ \\
\hline \multirow{12}{*}{ 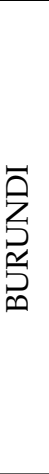 } & Burundi & 0.00 & -0.02 & 22.2 & 0.49 & 16.09 & -0.03 & 8.44 & 0.17 \\
\hline & Cameroon & 0.00 & -0.04 & -0.02 & 0.00 & 0.00 & -0.03 & -0.02 & 0.00 \\
\hline & Cote d'Ivoire & 0.00 & -0.03 & -0.10 & 0.00 & -0.01 & -0.03 & -0.03 & 0.00 \\
\hline & Ethiopia & 0.00 & -0.05 & 0.00 & 0.00 & -0.02 & -0.04 & -0.01 & 0.00 \\
\hline & Ghana & 0.00 & -0.03 & -0.10 & 0.00 & -0.02 & -0.03 & -0.03 & 0.00 \\
\hline & Guinea & 0.00 & -0.03 & -0.10 & 0.00 & -0.02 & -0.03 & -0.03 & 0.00 \\
\hline & Kenya & 0.00 & -0.06 & 0.04 & 0.00 & 0.00 & -0.04 & -0.01 & 0.00 \\
\hline & Madagascar & 0.00 & -0.04 & -0.04 & 0.00 & -0.02 & -0.03 & -0.02 & 0.00 \\
\hline & Malawi & 0.00 & -0.05 & 0.02 & 0.00 & -0.02 & -0.04 & -0.01 & 0.00 \\
\hline & Niger & 0.00 & -0.03 & -0.10 & 0.00 & -0.04 & -0.03 & -0.03 & 0.00 \\
\hline & South Africa & 0.00 & -0.04 & -0.04 & 0.00 & 0.00 & -0.03 & -0.02 & 0.00 \\
\hline & World trade & \multicolumn{4}{|c|}{0.02} & \multicolumn{4}{|c|}{0.01} \\
\hline \multirow{12}{*}{ 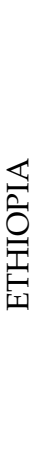 } & Burundi & 0.01 & -0.37 & 0.02 & 0.00 & -0.20 & -0.29 & -0.10 & 0.00 \\
\hline & Cameroon & 0.01 & -0.22 & -0.77 & 0.00 & -0.06 & -0.24 & -0.21 & 0.00 \\
\hline & Cote d'Ivoire & 0.01 & -0.21 & -0.79 & 0.00 & -0.05 & -0.24 & -0.21 & 0.00 \\
\hline & Ethiopia & 0.00 & -0.19 & 21.36 & 0.42 & 14.01 & -0.22 & 8.22 & -0.15 \\
\hline & Ghana & 0.01 & -0.22 & -0.75 & -0.01 & -0.15 & -0.24 & -0.21 & 0.00 \\
\hline & Guinea & 0.01 & -0.22 & -0.77 & -0.01 & -0.16 & -0.24 & -0.21 & 0.00 \\
\hline & Kenya & 0.01 & -0.53 & 0.80 & 0.01 & 0.01 & -0.35 & 0.01 & 0.00 \\
\hline & Madagascar & 0.00 & -0.21 & 0.78 & -0.01 & -0.23 & -0.23 & -0.21 & 0.00 \\
\hline & Malawi & 0.01 & -0.35 & -0.06 & 0.00 & -0.25 & -0.28 & -0.11 & 0.00 \\
\hline & Niger & 0.01 & -0.22 & -0.75 & -0.01 & -0.33 & -0.24 & -0.21 & 0.00 \\
\hline & South Africa & 0.00 & -0.20 & -0.78 & 0.00 & 0.00 & -0.23 & -0.21 & 0.00 \\
\hline & World trade & \multicolumn{4}{|c|}{0.19} & \multicolumn{4}{|c|}{0.06} \\
\hline
\end{tabular}

${ }^{1}$ Welfare; ${ }^{2}$ Expenditure spent on agriculture; ${ }^{3}$ all value is express as a percentage change from actual to counterfactual.

Increasing technology also benefits regional welfare, because increasing technology in any Sub-Saharan African country increases the welfare of all other countries in the region, within the range of 0.00 to $0.01 \%$ in case of mobile labor. However, in the case of immobile labor, only the beneficiary country, the neighboring countries, and countries with high GDP experience an increase in welfare. Local economies benefit more from the case of immobile labor. For example, for Burundi and Ethiopia, with immobile labor, welfare increases by $16 \%$ and $14 \%$, respectively. It is worth to note that Burundi and Malawi benefit the most from technology improvement with $18 \%$ and $16 \%$, respectively, and South Africa and Cote d'Ivoire benefit the least with only $0.2 \%$ and $2.5 \%$ increase of welfare. Finally, technology improvement increases agricultural expenditure especially in the local economy that increases its technology.

The simulation shows that increasing the technology parameters benefits the international market in two ways. The world's agricultural price decreases and agricultural global trade increases (according to Table 6). Table 7 shows that international markets benefit more from a mobile labor than immobile labor.

Table 7 shows the percentage change in the agricultural trade according to $25 \%$ increase of the technology parameters. The agricultural trade volume increases within the range of 0.02 to $0.19 \%$ according to the country that increase its agricultural technology. The technology improvement in Ethiopia, Kenya, and Madagascar benefits the most the international market for both mobile and immobile labor case. We present the effect of $100 \%$ increases in agricultural technology in this case to highlights the impact of the inefficiency of technology transfer in the Sub-Saharan Africa. We found identical pattern but with higher impact on international trade volume, increase in international trade volume is 4 -fold to 5 -fold higher than the effect from $25 \%$ increase of technology. 
Table 7. Global world trade increases from the simulation.

\begin{tabular}{ccc}
\hline Country & Mobile Labor & Immobile Labor \\
\hline Burundi & $0.02(0.1)$ & $0.001(0.03)$ \\
Cameroon & $0.04(0.16)$ & $0.01(0.05)$ \\
Cote d'Ivoire & $0.03(0.13)$ & $0.01(0.03)$ \\
Ethiopia & $0.19(0.75)$ & $0.07(0.23)$ \\
Ghana & $0.05(0.22)$ & $0.02(0.06)$ \\
Guinea & $0.03(0.13)$ & $0.01(0.03)$ \\
Kenya & $0.11(0.43)$ & $0.03(0.12)$ \\
Madagascar & $0.09(0.35)$ & $0.03(0.1)$ \\
Malawi & $0.05(0.22)$ & $0.02(0.06)$ \\
Niger & $0.05(0.22)$ & $0.02(0.06)$ \\
South Africa & $0.04(0.15)$ & $0.01(0.04)$ \\
\hline
\end{tabular}

Note: Values in parenthesis are the percentage change with $100 \%$ increase.

\section{Discussion}

\subsection{Comparative Advantage of the Agricultural Sector}

The $\theta$ value found in this study is between the interval set earlier, $(1.57,8.28)$ which is consistent with existing literature $[27,30,31,41]$. The value of $\theta$ being within $(1 ; 8.28)$ confirmed that agricultural products are more heterogeneous than manufactured products, and labor productivity is highly dispersed among the sample. Thus, labor in some sub-regions is more productive than labor in others. This result also indicated that a high inequality exists between sub-regions, which the SDG 2030 aims to reduce [42]. Moreover, it emphasized a large gap between labor productivity in LDCs and developed countries [4-6]. Low productivity in LDCs explained their lower value of agricultural export. Since agriculture is a rainfed activity, besides technology, the differences in productivity might also come from the large differences in temperature, precipitation, growing season, and soil type across the world [35,43], but this is beyond the model's measurement and scope.

Existing literature found $\theta \in[1.57,8.28]$, Reimer and $\mathrm{Li}$ (2010) [35], using agricultural crop found $\theta \in[2.52,4.96]$; Alvarez and Lucas (2007), and Costinot et al. (2012) [33,44] in their study, found $\theta$ equal to 4.47 and 6.67, respectively. Tombe (2015) [6] found a value of 6.02 for agricultural products in his work. Previous research found that in the trade of agricultural products, comparative advantage has a large impact on trade, which is in line with our findings.

\subsection{Agricultural Competitiveness in Sub-Saharan Africa}

Competitiveness is not only a matter of one factor but is the results of the combination of multiple factors as proposed in Porter's Diamond [45]. Hence, even with low wages, African and South Asian countries are not competitive. In the opposite case, European countries $\left(T_{i}=65.30\right)$ have higher value of technology parameter than the countries in Oceania $\left(T_{i}=48.73\right)$. However, European competitiveness $\left(S_{i}=0.01\right)$ is lower than Oceania's $\left(S_{i}=1.40\right)$. These cases reflect the effect of the ratio of productivity to wages on the competitiveness level. African countries are disadvantaged by their low labor productivity; African agricultural labor only generates 1370 USD per year against 226,000 USD for Argentina and 114,000 USD for the U.S. In line with previous studies, we found a significant difference between the technology used in agriculture in Sub-Saharan Africa and in developed countries (Sub-Saharan Africa's technology coefficient value was evaluated to be equal to 0.16 and European's one, equal to 65.30) [6,30,33]. Reimer and Li (2010) [35] found that France and Italy's yield are twice higher than the average world yield. Morocco and Ethiopia's yield are $100 \%$ and $60 \%$, respectively lower than the average world yield.

Using the extension in the EK model, [27], low competitiveness of LDCs could be explained by:

(1) According to the 2SLS results, labor productivity governs the competitiveness. Effectively, even with low wages but also low production, Africa and South Asia cannot 
compete with others. Moreover, the choice of technology is important as it could have a negative impact on the competitiveness. Inadequate technology could worsen the productivity gap.

(2) Low competitiveness can be explained by a low capital allocated to the agricultural R\&D field in Sub Saharan Africa (0.002 USD million/agricultural labor/year) and in South Asia (0.001 USD million/agricultural labor/year). This is low compared to North America (11.9 USD million/agricultural labor/year). According to Porter [45], LDCs are still in the first stage of development. They do not have enough capital to improve their productivity so they do not have enough agricultural goods to supply the local market and the international market [46-48]. Within the African sample, Cote d'Ivoire and South Africa are the most productive. They are among the countries with higher GDP, so, capital allocated for the agricultural R\&D field is higher than the rest of the Sub-Saharan African countries (0.08 and 0.001 USD million/agricultural labor/year for South Africa and Cote d'Ivoire). In our study, the agricultural R\&D was used as a proxy for the technology variable as mentioned by Narula (1993) [49]. This finding showed that lack of labor productivity is associated with low competitiveness for the African countries in the sample.

(3) Finally, low educational attainment of labor, with an average of 4.16 and 4.87 years of schooling for the Sub-Saharan Africa and South Asia against 11.95 years of schooling for North America, also contributes to low competitiveness. This result indicated that LDCs face a serious lack of capital, infrastructure, and educational skills.

\subsection{Technological Innovation in the Agricultural Sector}

In a global context, there is a high gap between the aims of the countries in improving their technology. Developed countries tend to invest more in sustainable agriculture and waste reduction [50], while LDCs are still struggling with auto-subsistence. For most LDCs, technological innovation and the global trade volume are positively correlated [21]. Poor countries benefit more from the technology increase than country with higher GDP [27]. Indeed, according to the rules of decreasing marginal return, more developed country will benefit less from the increase of one input compared to less developed country.

It is worth noting that with low educational attainment, African labor is likely to stay immobile. Its agricultural labor cannot shift to the information and technology sectors for example. At the same time, labor from other sectors do not find the agricultural sector appealing, due to its low wage. As a result, labor migration in Africa is more rural-urban than urban-rural or rural-rural [51]. However, with an immobile labor, most of the Sub-Saharan African countries will not enjoy the maximum benefit from technological improvement. In this case, even if local economies get higher benefit from the technology improvement, the regional economy are subject to a decrease of welfare. Moreover, the effect of technology improvement with immobile labor is lower than the effect with mobile labor. Thus, it is needed to combine technological innovation with an educational improvement because the use of technology in agriculture is often inhibited by educational attainment [52]. We showed the difference of the impact of $100 \%$ increase and $25 \%$ is about 4 -fold to 5 -fold. Countries that allocate higher capital to the agricultural R\&D field would gain more from technological innovation, and higher education attainment would facilitate this technological innovation.

In addition to the global benefits from technological innovation in the agricultural sector in Sub-Saharan Africa, technological improvement also addresses the first and the tenth goal of SDG. It would increase the welfare and the consumption power of precarious producers in LDCs. Finally, it would help achieve the second goal of SDG by increasing the world food supply and lowering world food price.

The most efficient way to transfer technology is through FDI [53,54]. Despite low income and lack of agricultural production in Sub-Saharan Africa, foreign investors are reluctant to invest because they will face social, cultural, and institutional challenges [55]. However, investors have an interest in investing in Sub-Saharan Africa, especially in the 
agricultural sector. Following the concept of log-supermodularity, a country with educated labor gains more in an activity that requires more technology such as high-tech sector. Therefore, in the short term, our findings suggest that Sub-Saharan Africa should specialize in activities that require lower labor skills such as agriculture. It is a land-based activity and requires less training than other activities. However, in the long term, improving education in Sub-Saharan Africa will maximize the benefit from FDI. For a region that is subject to a lack of capital, a loan from the development bank could also help in the instauration of a good business environment [56]. Based on their respective strengths, countries can specialize in agriculture if the agricultural sector is relatively more productive than the manufacturing sector. We found that most LDCs, like Sub-Saharan Africa, should specialize in the agricultural sector.

\section{Conclusions}

This study examined the comparative advantage and competitiveness of agriculture in Sub-Saharan Africa. We assessed the importance of technological innovation in agriculture in Sub-Saharan Africa on world trade. We found $\theta=4.0875$ implying that comparative advantage in agriculture has a larger impact on trade than the distance variable. The results showed that Sub-Saharan Africa has low competitiveness compared to other regions. It is generally due to its low labor productivity, and the low value of its technology parameters which is equal to 0.16. However, technological improvement in any country in SubSaharan Africa, here by $25 \%$, would increase the agricultural world trade volume within a range of 0.02 to $0.19 \%$. This technology improvement would benefit African producers because it would increase the local wage and country welfare. Furthermore, it would help achieve global food security by increasing agricultural productivity in Sub-Saharan Africa. However, technology transfer could be inhibited by labor educational attainment. With an efficient technology transfer, a hypothetical increase of the technology parameter by $100 \%$ would impact world trade volume by 4 -fold to 5 -fold higher than the effect from $25 \%$ increase. Therefore, a combination of technological innovation and education improvement is recommended.

This study addresses the SDG 2030 in three ways: first, we show that increasing agricultural technology in Sub-Saharan Africa benefits the local, regional, and global economies. By doing so, it helps achieve the goal of SDG 2030 eradicate poverty and to reduce the gap between countries. Second, we show that by increasing Sub-Saharan African technology, both local and international price decrease. A lower agricultural price benefits local and foreign consumer and increases the affordability of food. Finally, it increases world agricultural supply and ensures food security.

A similarity between Sub-Saharan Africa and South Asia was also found in this study. Both have low competitiveness that comes from the low productivity of their labor. Thus, the findings from this study can be extended to the South-Asia countries and other LDCs. Our research could be used as an instrument to establish adequate policy in agricultural production. We oriented policymakers to invest more in the agricultural sector and provide adequate technology to improve the labor productivity of Sub-Saharan Africa. Most importantly, we highlight that labor quality must be improved in rural areas in order to maximize gains from technology improvement. Our analysis is limited by the sample size as we were unable to include all Sub Saharan African countries in the sample due to data unavailability. Finally, this study can help foreign investors in their decisions when investing in agriculture in Sub-Saharan Africa. However, FDI implementation cost and hostile environments linked to political instability; unstable economic structure may be factors that could stop multinational enterprises from entering the LDCs' market. Further research is needed to compare the benefits from producing through multinational enterprises versus entering the international market by trading. 
Author Contributions: Conceptualization, M.H.A. and P.Y.; methodology, M.H.A. and P.Y.; software, M.H.A.; validation, M.H.A. and P.Y.; formal analysis, M.H.A.; data curation, M.H.A.; writingoriginal draft preparation, M.H.A.; writing-review and editing M.H.A.; visualization, M.H.A.; supervision, P.Y. All authors have read and agreed to the published version of the manuscript.

Funding: This research received no external funding.

Institutional Review Board Statement: Not applicable.

Informed Consent Statement: Not applicable.

Data Availability Statement: Publicly available datasets were analyzed in this study. This dataset has been addressed in the references [3,37].

Conflicts of Interest: The authors declare no conflict of interest.

\section{References}

1. Bastiat, F. Selected Essays on Political Economy, Trans. Seymour Cain; Huszar, G.B.d., Ed.; Foundation for Economic Education: New York, NY, USA, 1995.

2. Acharyya, R.; Kar, S. International Trade and Economic Development; Oxford University Press: Oxford, UK, 2014; ISBN 978-0-19967285-1.

3. World Bank. The World Bank Database. Available online: https://data.worldbank.org/indicator/AG.LND.ARBL.HA?locations= MG (accessed on 6 December 2020).

4. Caselli, F. Accounting for Cross-Country Income Differences; National Bureau of Economic Research: Cambridge, MA, USA, 2004; p. w10828.

5. Gollin, D.; Lagakos, D.; Waugh, M.E. The Agricultural Productivity Gap. Q. J. Econ. 2014, 129, 939-993. [CrossRef]

6. Tombe, T. The Missing Food Problem: Trade, Agriculture, and International Productivity Differences. Am. Econ. J. Macroecon. 2015, 7, 226-258. [CrossRef]

7. Fuglie, K.; Gautam, M.; Goyal, A.; Maloney, W. Technology and Productivity Growth in Agriculture; World Bank: Washington, DC, USA, 2020.

8. OECD. Food and Agriculture Organization of the United Nations. OECD-FAO Agricultural Outlook 2016-2025; OECD-FAO Agricultural Outlook; OECD: Paris, France, 2016; ISBN 978-92-64-25322-3.

9. Shimeles, A.; Verdier-Chouchane, A.; Boly, A. Introduction: Understanding the Challenges of the Agricultural Sector in SubSaharan Africa. In Building a Resilient and Sustainable Agriculture in Sub-Saharan Africa; Shimeles, A., Verdier-Chouchane, A., Boly, A., Eds.; Springer International Publishing: Cham, Switzerland, 2018; pp. 1-12. ISBN 978-3-319-76221-0.

10. Bjornlund, V.; Bjornlund, H.; Van Rooyen, A.F. Why Agricultural Production in Sub-Saharan Africa Remains Low Compared to the Rest of the World-A Historical Perspective. Int. J. Water Resour. Dev. 2020, 36, S20-S53. [CrossRef]

11. IFAD Africa's Agricultural Potential. Available online: https:/ / farmingfirst.org/AfricanAg-Mobile (accessed on 15 December 2020).

12. Verdier-Chouchane, A.; Karagueuzian, C. Moving towards a Green Productive Agriculture in Africa: The Role of ICTs. Afr. Econ. Brief 2016, 7, 1-9.

13. Jiménez-Almazán, M.; Uribe-Toril, J.; Ruiz-Real, J.L. International Trade and Sustainability: Bibliometric and Cluster Analysis. Sustainability 2020, 12, 6816. [CrossRef]

14. Smith, A. An Inquiry into the Nature and Causes of the Wealth of Nations. Available online: www.econlib.org/library/Smith/ smWN.html (accessed on 1 November 2020).

15. Ricardo, D. On the Principles of Political Economy and Taxation. Available online: https://www.econlib.org/library/Ricardo/ ricP.html (accessed on 1 November 2020).

16. Balassa, B. Trade Liberalisation and "Revealed" Comparative Advantage. Manch. Sch. 1965, 33, 99-123. [CrossRef]

17. Krugman, P.R. Increasing Returns, Monopolistic Competition, and International Trade. J. Int. Econ. 1979, 9, 469-479. [CrossRef]

18. Costinot, A. An Elementary Theory of Comparative Advantage. Econometrica 2009, 77, 1165-1192. [CrossRef]

19. MacDougall, G.D.A. British and American Exports: A Study Suggested by the Theory of Comparative Costs. Part II. Econ. J. 1952, 62, 487-521. [CrossRef]

20. MacDougall, G.D.A. British and American Exports: A Study Suggested by the Theory of Comparative Costs. Part I. Econ. J. 1951, 61, 697-724. [CrossRef]

21. Stern, R.M. British and American Productivity and Comparative Cost in International Trade. Oxf. Econ. Pap. 1962, 14, 275-296. [CrossRef]

22. Deardorff, A.V. Chapter 10 Testing trade theories and predicting trade flows. In Handbook of International Economics; Elsevier: Amsterdam, The Netherlands, 1984; Volume 1, pp. 467-517. ISBN 978-0-444-86792-6.

23. Heckscher, E.F.; Ohlin, B.; Flam, H.; Flanders, M.J. Heckscher-Ohlin Trade Theory; MIT Press: Cambridge, MA, USA, 1991; ISBN 978-0-262-08201-3.

24. Leamer, E.; Levinsohn, J. International Trade Theory: The Evidence; National Bureau of Economic Research: Cambridge, MA, USA, 1994; p. w4940. 
25. Deardorff, A.V. The Ricardian Model; Research Seminar in International Economics; University of Michigan: Ann Arbor, MI, USA, 2007; pp. 1168-1174.

26. Dornbusch, R.; Fisher, C.S.; Samuelson, P.A. Comparative Advantage, Trade, and Payments in a Ricardian Model with a Continuum of Goods. Am. Econ. Rev. 1977, 67, 823-839.

27. Eaton, J.; Kortum, S. Technology, Geography, and Trade. Econometrica 2002, 70, 1741-1779. [CrossRef]

28. Chor, D. Unpacking Sources of Comparative Advantage: A Quantitative Approach. J. Int. Econ. 2010, 82, 152-167. [CrossRef]

29. Eaton, J.; Kortum, S.; Kramarz, F. An Anatomy of International Trade: Evidence From French Firms. Econometrica 2011, 79, 1453-1498. [CrossRef]

30. Levchenko, A.A.; Zhang, J. The Evolution of Comparative Advantage: Measurement and Welfare Implications. J. Monet. Econ. 2016, 78, 96-111. [CrossRef]

31. Shikher, S. Putting Industries into the Eaton-Kortum Model. JITED 2012, 21, 807-837. [CrossRef]

32. Simonovska, I.; Waugh, M.E. The Elasticity of Trade: Estimates and Evidence. J. Int. Econ. 2014, 92, 34-50. [CrossRef]

33. Costinot, A.; Donaldson, D. Ricardo's Theory of Comparative Advantage: Old Idea, New Evidence. Am. Econ. Rev. 2012, 102, 453-458. [CrossRef]

34. Heerman, K.E.R. Technology, Ecology and Agricultural Trade. J. Int. Econ. 2020, 123, 103280. [CrossRef]

35. Reimer, J.J.; Li, M. Trade Costs and the Gains from Trade in Crop Agriculture. Am. J. Agric. Econ. 2010, 92, 1024-1039. [CrossRef]

36. ITC Trade Statistics for International Business Development. Available online: https:/ / www.trademap.org (accessed on 1 October 2020).

37. UNCTAD UNCTAD. Available online: https:/ / unctad.org/statistics (accessed on 1 October 2020).

38. Head, K.; Mayer, T. Gravity Equations: Workhorse, Toolkit, and Cookbook. In Handbook of International Economics; Elsevier: Amsterdam, The Netherlands, 2014; Volume 4, pp. 131-195. ISBN 978-0-444-54314-1.

39. Danquah, M. Technology Transfer, Adoption of Technology and the Efficiency of Nations: Empirical Evidence from Sub Saharan Africa. Technol. Forecast. Soc. Chang. 2018, 131, 175-182. [CrossRef]

40. Dhehibi, B.; Rudiger, U.; Moyo, H.P.; Dhraief, M.Z. Agricultural Technology Transfer Preferences of Smallholder Farmers in Tunisia's Arid Regions. Sustainability 2020, 12, 421. [CrossRef]

41. Shikher, S. Capital, Technology, and Specialization in the Neoclassical Model. J. Int. Econ. 2011, 83, 229-242. [CrossRef]

42. United Nations. Transforming Our World: The 2030 Agenda for Sustainable Development; United Nations Publications: New York, NY, USA, 2020; p. 41.

43. FAO Gloabl Agro-Ecological Zones. Available online: http:/ /www.fao.org/nr/gaez/en/ (accessed on 1 October 2020).

44. Alvarez, F.; Lucas, R.E. General Equilibrium Analysis of the Eaton-Kortum Model of International Trade. J. Monet. Econ. 2007, 54, 1726-1768. [CrossRef]

45. Porter, M.E. The Competitive Advantage of Nations; Free Press: New York, NY, USA, 1990; ISBN 978-0-02-925361-8.

46. Al-Hiary, M.; Al Zu'bi, B.; Jabarin, A. Assessing Porter's Framework for National Advantage: The Case of Jordanian Agricultural Sector. Jordan J. Agric. Sci. 2010, 6, 11-26.

47. Huo, D.; Chen, Y.; Hung, K.; Song, Z.; Guan, J.; Ji, A. Diamond Model and the Export Competitiveness of the Agriculture Industry from Emerging Markets: An Exploratory Vision Based on a Spatial Effect Study Using a Genetic Algorithm. Econ. Res.-Ekon. Istraz. 2019. [CrossRef]

48. Smit, A. The Competitive Advantage of Nations: Is Porter's Diamond Framework a New Theory That Explains the International Competitiveness of Countries? South. Afr. Bus. Rev. 2010, 14, 105-130.

49. Narula, R. Technology, International Business and Porter's "Diamond": Synthesizing a Dynamic Competitive Development Model. MIR 1993, 33, 85-107.

50. Fortunati, S.; Morea, D.; Mosconi, E.M. Circular Economy and Corporate Social Responsibility in the Agricultural System: Cases Study of the Italian Agri-Food Industry. Agric. Econ. 2020, 66, 489-498. [CrossRef]

51. UNCTAD. Economic Development in Africa Report 2018: Migration for Structural Transformation. Chapiter 3: Contemporary Labour Migration; United Nations Publications: New York, NY, USA, 2018.

52. Uematsu, H.; Mishra, A.K.; Uematsu, H.; Mishra, A.K. Can Education Be a Barrier to Technology Adoption? In Proceedings of the Agricultural and Applied Economics Association Annual Meeting, Denver, CO, USA, 25-27 July 2010. [CrossRef]

53. Belloumi, M. The Relationship between Trade, FDI and Economic Growth in Tunisia: An Application of the Autoregressive Distributed Lag Model. Econ. Sys. 2014, 38, 269-287. [CrossRef]

54. Damijan, J.P.; Knell, M.; Majcen, B.; Rojec, M. The Role of FDI, R\&D Accumulation and Trade in Transferring Technology to Transition Countries: Evidence from Firm Panel Data for Eight Transition Countries. Econ. Sys. 2003, 27, 189-204. [CrossRef]

55. Ying, X. Chinese Agricultural and Manufacturing Investment in Kenya: A Scoping Study; China Africa Research Initiative: Washington, DC, USA, 2019.

56. Morea, D.; Balzarini, M. Bankability of a Public Private Partnership in Agricultural Sector: A Project in Sub Saharan Africa. Agric. Econ. 2019, 65, 212-222. [CrossRef] 